\title{
Hyperimmune Bovine Colostrum
}

National Cancer Institute

\section{Source}

National Cancer Institute. Hyperimmune Bovine Colostrum. NCI Thesaurus. Code C78491.

A dietary supplement consisting of bovine colostrum, containing high titers of immunog lobulins (Igs), with immunostimulating and anti-infective activities.

Hyperimmune bovine colostrum is harvested during the first days after calving from cows that have been inoculated repeatedly with specific pathogens during pregnancy. In addition to high titers of anti-pathogen specific antibodies, hyperimmune colostrum is also rich in other immune factors, proline-rich polypeptides (PRP), lactoferrin, glycoproteins, lactalbumins, cytokines, growth factors, vitamins, and minerals. This dietary supplement may exhbit anti-infective activity in immunocompromised patients. 